\title{
Local wisdom-based story calendar: Improving student's narrative writing skills in elementary school
}

\author{
Ali Mustadi, Primary Education Department of Graduate School Universitas Negeri Yogyakarta, Indonesia, \\ ali_mustadi@uny.ac.id,ORCID: 000-0002-7620-4582 \\ Moh. Farizqo Irvan, Primary Education Department of Graduate School Universitas Negeri Yogyakarta, \\ Indonesia, mohfarizqo.2018@student.uny.ac.id, ORCID: 000-0001-5450-8078
}

\begin{abstract}
The research aims to: (1) develop a local wisdom-based story calendar to improve narrative writing skills and (2) reveal the effectiveness of the developed story calendar. This research was R \& D applying Brog \& Gall model (1983). The subjects were fourth-grade students of elementary schools in Semarang, Indonesia. The data collection was through observation, interviews, and questioners. The data analysis used the independent sample t-test at the significance level of 0.05 . The results of the research show that: (1) the developed story calendar has passed the criteria of feasibility with very good criteria; (2) the local wisdom-based story calendar is effective to improve the narrative writing skills based on the t-test results with a significance level of $<0.05$, that is 0.000 . Through the pictures, local wisdom-based stories, and some literacy activities in the developed story calendar, elementary students can write narrative text more directed and easily.
\end{abstract}

Keywords: Local wisdom, story calendar, narrative writing skills, elementary students Received: 22.11.2020 Accepted: 14.12.2020 Published: 13.01.2021

\section{INTRODUCTION}

The application of $21^{\text {st }}$-century learning emphasizes the provision of students to four basic skills which include critical thinking, collaboration, communication, and creative skills in dealing with challenges and life problems (Erdogan, 2019). One of the four skills is communication. Iksan et al. (2012) mentioned that communication skills are skills in the process of exchanging information that runs intensively in the formation of knowledge. Communication can be carried out both orally and in writing (Prabavathi \& Nagasubramani, 2018). Communication skills become a very important aspect needed in the academic world (Khan \& Rahman, 2017), career development, and industry (Mahajan, 2015). In addition to communication skills, creativity is also a skill that supports one's success (Egan, Maguire, Christophers, \& Rooney, 2017; Tan, Lee, Ponnusamy, Koh, \& Tan, 2016). Birgili (2015) mentioned that creativity is a cognitive thought process in dealing with an object, event, or problem that is confronted with a new perspective based on the capacity of the individual. The provision of both skills at the same time can be done through language learning in elementary schools.

In elementary school, language learning consists of four skills. One of the skills is writing. Sheth (2016) stated that writing is productive and expressive activity. For high-grade elementary students, writing skills are trained by writing some type of texts. One of the texts is a narrative text. Moya, Ortíz, \& Díaz (2016) and Ulu (2019) described the narrative text as a text in the form of a story where the storyline is explained coherently by including elements such as main characters, places, times, goals, responses, which are generally of interest to students in the first year of elementary and high school. Narrative essay writing activities for students can affect cognitive and affective skills of students (Aziz, Narayanasamy, Mohamad, \& Hameed, 2019), learning outcomes (Lance \& Beverly, 2012), creativity (Istiq'faroh, Suhardi, \& Mustadi, 2020; Pishghadam \& Mehr, 2011), and support communication skills (Tuan, 2010). In narrative writing, the activities combine communication skills through written language and develop creativity through the process of imagination. It is expected that through these activities, students can develop two skills at once.

The writing skills in elementary school are still in the form of practice, but students need to have the motivation to learn to write well. However, the facts show that the literacy rate (reading and writing) of students in Indonesia is still relatively low. Based on the research results of the Program for International Students Assessments (PISA) in 2015, Indonesia ranked 64t ${ }^{\text {th }}$ out of 72 countries studied (OECD, 2016). A survey conducted by Central Connecticut State University in 2016 on state literacy ratings also showed the same outcomes, in which Indonesia ranked $60^{\text {th }}$ out of 61 countries surveyed (Detik.com, 2019). Data from the Progress in International Reading Literacy Study (PIRLS) in 2011 
showed that the reading ability of fourth-grade elementary school students ranked $45^{\text {th }}$ out of 48 (IEA, 2012). Based on these data, it can be concluded that the literacy ability of students in Indonesia is still below the average compared to other countries in the world. Even though most of the surveys are in the form of reading surveys, as previously explained, language skills are interrelated with one another, including students' writing skills (Kim, Petscher, Wanzek, \& Al Otaiba, 2018).

The survey data described above are in line with the data obtained in the preliminary study in several elementary schools in Semarang. Based on the preliminary study, information was obtained that the students' narrative essay writing skills were still not optimal. That is because the students' low interest in reading affects the students' understanding (Endah, Effendi Thahar, \& Asri, 2018). Moreover, students also do not recognize the surrounding environment well. In fact, the latest 2013 curriculum development must contain the values of local wisdom, including in developing teaching materials and media. Apparently, the observation results showed that the local wisdom-based learning media that supports the learning of students' narrative essay writing is unavailable.

The development of local wisdom-based media is very important in supporting learning. Media and teaching materials that are developed based on local wisdom will be easier to understand because students learn from things near them first (Wang \& Wang, 2015). Environment-based learning will support contextual and meaningful learning (Anggraini \& Kusniarti, 2017). Thus, the development of learning and media for elementary school children should be based on local wisdom. Santosa, Basuki, \& Puspita (2019) argued that the development of learning materials based on local wisdom is effective in improving students' narrative writing skills. The development of learning media should be adjusted to the needs of teachers and students. Thereby, learning objectives can be achieved (Zubaidah, 2015).

In the $21^{\text {st }}$ century, the use of instructional media strongly supports learning success (Khoirunnisa, Umamah, \& Sumardi, 2019; Sakat et al., 2012). According to Naz \& Akbar (2010), learning media has a role to clarify the material, attract the attention of students, so they can be understood by students. Learning media can also direct students to focus more on learning. One of them is a local wisdom-based story calendar. Story calendar media is a type of picture book media that contains activities that support the development of student literacy (USAID, 2014). There are several studies on the use of story calendar media in learning. For example, Anggraeni (2017) used story calendar media to improve the reading skills of elementary school students. Then, Hermanto \& Anisyah (2017) developed a story calendar based on character values to improve the character of elementary school students in the early grade.

The local wisdom-based story calendar, as an effective learning media, is expected to support student's narrative writing skills. Although the story calendar is used in other skills like reading comprehension (Anggraeni, 2017) or early reading and writing (Sa'idah, Pramuniati, \& Eviyanti, 2019), the study about using local wisdom-based story calendar to improve student's narrative writing skills in Indonesian language subject is still rarely explored. The aims of this study are to (1) develop a local wisdom-based story calendar to improve narrative writing skills and (2) reveal the effectiveness of the developed story calendar.

\section{METHODS}

\section{Research design}

This research used a research and development model that has been developed by Borg and Gall (1983). The local wisdom-based story calendar was developed based on ten procedures. The procedures were: (1) research and information collecting, (2) planning, (3) developing, (4) preliminary field testing, (5) main product revision, (6) main field testing, (7) operational product revision, (8) operational field testing, (9) final product revision, and (10) dissemination and implementation.

\section{Subjects}

The subjects of this study were teachers and fourth-grade elementary school students in Semarang City, Central Java, Indonesia. For a preliminary field test, the subjects were 35 fourth-grade students and a teacher of Elementary School 06 of Purwoyoso. In the extended-primary field test, it consisted of 63 fourth-grade students and two teachers of Elementary School 02 of Ngaliyan and Elementary School 01 of Purwoyoso, and for the operational field test, it used 82 fourth-grade students from other schools before.

\section{Data collection techniques and instruments}

The data collection techniques in this study consisted of interviews, observation, questioners, scale, and test. The instruments in this study were divided into two groups. The first instrument was to measure the validity media: 1) materials expert's sheet of validity, 2) media expert's scale of validity, 3) teacher's 
response scale toward media, 4) students' response scale toward media. The second was instruments of pre-test and post-test to measure the effectiveness of media on student's narrative writing skills.

\section{Data analysis techniques}

The study used qualitative and quantitative techniques to analyze the data. The qualitative data were analyzed using descriptive analysis. The descriptive analysis technique was used to analyze the need assessment results. For the feasibility of the developed story calendar based on material and media experts, teacher's and student's responses were analyzed by converted the quantitative data into five qualitative categories. The quantitative data to measure the effectiveness of developed media were analyzed by using statistical analysis of the t-test. The effectiveness of the local wisdom-based story calendar in improving student's narrative writing skills was analyzed by independent $t$-test and paired $t$ test. The t-test was carried out when it fulfilled the previous prerequisite test, which was the normality and homogeneity test.

\section{RESULTS}

\section{Description of the developed product}

The local wisdom-based story calendar developed in this study consist of three main components. They were: 1) pictures that helped to illustrate stories, 2) local wisdom-based stories, 3) literacy activities that supported narrative writing skills. The local wisdom-based story calendar has a picture element as a supporting story. The images used are a combination of real images for the setting of the place and animated images for the characters in the story. The use of images is to assist students in imagining the setting of the story while recognizing the condition of their environment. Local wisdom-based stories provide stimulus to students. Students will find it easier to learn something if it is related to their surrounding environment. So, learning becomes more meaningful. Local wisdom-based story calendar media are also supported by literacy activities that support writing skills. There are six activities contained in the media, including: a) listening to the story, b) creating a graphic organizer or mind map, c) analyzing the characters, d) making the outline, e) developing the outline into a story, and f) giving opinions if they become one of the characters in the story.

The developed media was designed with Adobe Photoshop and Adobe Illustrator programs with ivory paper material with a thickness of 310-grams for the cover and contents. The selection of thick paper is intended to facilitate students or teachers in turning the calendar pages and making the media more durable. The size of the story calendar media is arranged in two sizes. The large size for classical learning is $30.5 \mathrm{~cm} \times 48.7 \mathrm{~cm}$ (A3+ paper size) and the small size is $21 \mathrm{~cm} \times 29.7 \mathrm{~cm}$ (A4 paper size) for group or individual learning. The local wisdom-based story calendar was visualized in Figure 1.

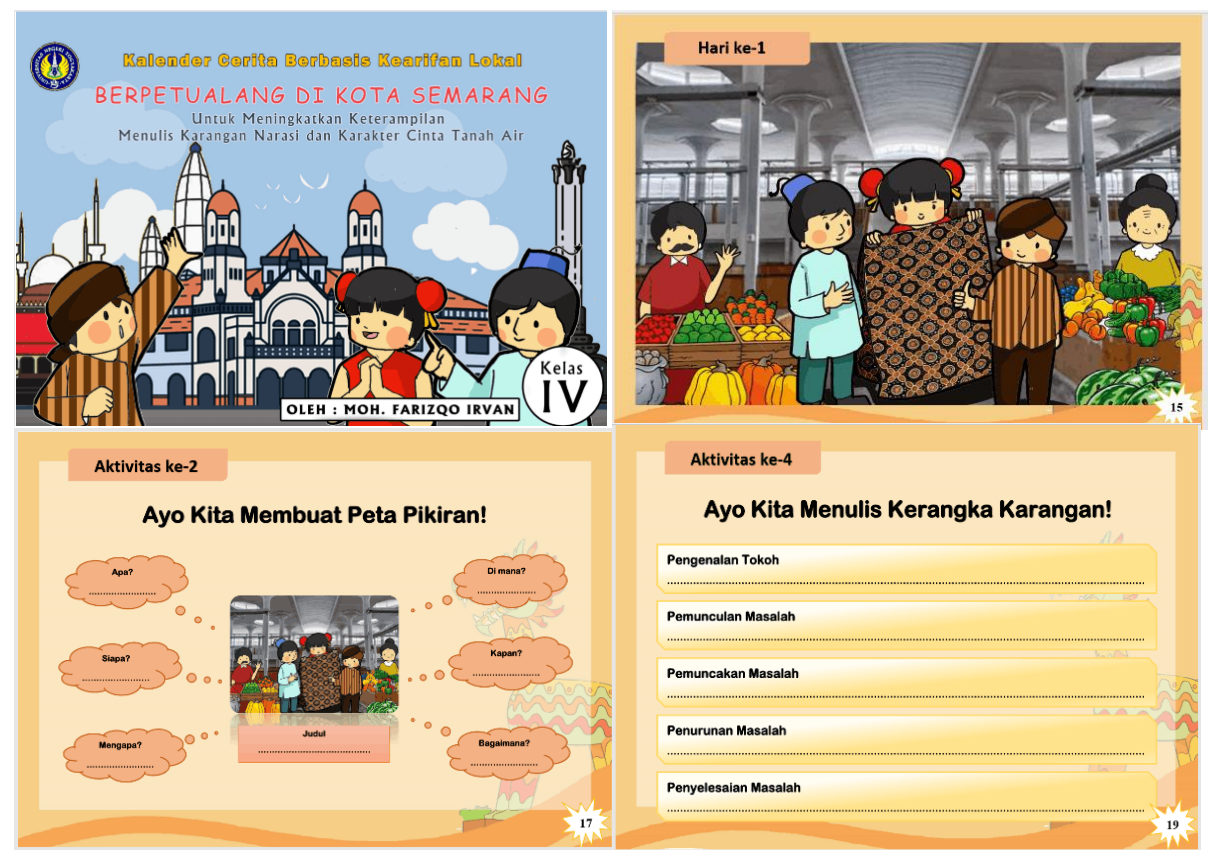

Figure 1. The local wisdom-based Story Calendar "Berpetualang di Kota Semarang" 


\section{Results of material and media expert validation}

Before trying the developed story calendar in preliminary, main, and operational field testing, the local wisdom-based story calendar was validated by a material and a media expert. Aspects assessed by the material expert include conformity, importance, learnability, attractiveness, and benefit. The assessment results from the material expert is shown in Table 1 below.

Table 1. The assessment results from the material expert

\begin{tabular}{|l|l|l|l|}
\hline No & Aspect & Score & Category \\
\hline 1 & Conformity & 25 & Very Good \\
\hline 2 & Importance & 18 & Very Good \\
\hline 3 & Learnability & 29 & Very Good \\
\hline 4 & Attractiveness & 14 & Very Good \\
\hline 5 & Benefit & 10 & Very Good \\
\hline The total score for whole aspects & $\mathbf{9 6}$ & Very Good \\
\hline
\end{tabular}

As shown in Table 1, the material expert assessed the developed story calendar in five aspects. The conformity aspect obtained a score of 25 with a very good category. The score of the importance of the developed story calendar was 18 with a very good category. The learnability aspect obtained a score of 29 with a very good category. The score of the attractiveness of the developed story calendar was 14 with a very good category. The benefit aspect obtained a score of 10 with a very good category. The total score for all aspects was 96 with a very good category. It can be concluded that the local wisdom-based story calendar has very good criteria from the material expert's assessment results generally.

There are five aspects that assessed by the media expert. These five aspects assessed include consistency, format, organization, attractiveness, and font. The assessment results from the material expert is shown in Table 2 below.

Table 2. The assessment results from the media expert

\begin{tabular}{|l|l|l|l|}
\hline No & Aspect & Score & Category \\
\hline 1 & Consistency & 10 & Very Good \\
\hline 2 & Format and Layouts & 15 & Very Good \\
\hline 3 & Material Organization & 24 & Very Good \\
\hline 4 & Attractiveness & 32 & Very Good \\
\hline 5 & Font & 15 & Very Good \\
\hline \multicolumn{2}{|l}{ The total score for whole aspect } & $\mathbf{9 6}$ & Very Good \\
\hline
\end{tabular}

As shown in Table 2, the media expert assessed the developed story calendar in five aspects. The consistency aspect obtained a score of 10 with a very good category. The score of the format and layouts of the developed story calendar was 15 with a very good category. The material organization aspect obtained a score of 24 with a very good category. The score of the attractiveness of the developed story calendar was 32 with a very good category. The font aspect obtained a score of 15 with a very good category. The total score for all aspects was 96 with a very good category. It can be concluded that the local wisdom-based story calendar has very good criteria from the media expert assessment results generally.

\section{Trial results of the product}

At the beginning of the development, the study was started by conducting a needs analysis through interviews, observations, and literature review. After the draft of the developed story calendar was created, the developed media were validated by material and media experts and continued with trial testing.

The first stage was a preliminary field test. The preliminary field test involved 35 fourth-grade students and a fourth-grade teacher. Based on the preliminary field test, the developed media obtained a score of 72 for the teacher's response and 13.36 for the student's response. Both were good category and passed the standard score.

The next stage was the main field test. The main field test involved 63 fourth-grade students and two fourth-grade teachers. The overall results of the teacher's response score were 90.5 and included in the very good category. The results of the student's response score for the developed story calendar were 14.56 and included in the very good category. The results of the teacher's and student's response scores 
indicate that the local wisdom based-story calendar was feasible to be tasted in the next stage, the operational field testing.

Table 3. Results of the teacher's response score in main field testing

\begin{tabular}{|l|l|l|l|l|}
\hline No & Aspect & Score & Category \\
\hline & & $\mathbf{1}^{\text {st }}$ Teacher & $\mathbf{2}^{\text {nd }}$ Teacher & \\
\hline 1 & Narrative text & 12 & 14 & Very Good \\
\hline 2 & Language & 16 & 17 & Very Good \\
\hline 3 & Content of Media & 10 & 10 & Very Good \\
\hline 4 & Convenience using Media & 18 & 17 & Very Good \\
\hline 5 & Material Conformity & 19 & 19 & Very Good \\
\hline 6 & Student's Characteristics & 14 & 13 & Very Good \\
\hline \multicolumn{2}{|l}{ The total score for whole aspect } & $\mathbf{8 9}$ & $\mathbf{9 2}$ & Very Good \\
\hline
\end{tabular}

Table 4. Results of the student's response score in main field testing

\begin{tabular}{|l|l|l|l|}
\hline No & Aspect & Score & Category \\
\hline 1 & Attractiveness & 4.86 & Very Good \\
\hline 2 & Convenience using Media & 2.86 & Very Good \\
\hline 3 & Material Conformity & 3.90 & Very Good \\
\hline 4 & Student's Characteristics & 2.94 & Very Good \\
\hline \multicolumn{2}{|l|}{ The total score for whole aspect } & $\mathbf{1 4 . 5 6}$ & Very Good \\
\hline
\end{tabular}

The next stage was conducted to determine how effective the local wisdom based-story calendar towards the student's narrative writing skills. The effectiveness of the developed story calendar was determined by the results of the operational field testing. The test was conducted in three classes from three different schools in Semarang City which were divided into one control group class and two experimental class. Table 5 below shows the student's narrative writing skills in control and experimental classes.

Table 5. Results of pre-test and post-test student's narrative writing skills

\begin{tabular}{|l|l|l|l|l|l|}
\hline \multirow{2}{*}{ No. } & \multirow{2}{*}{ Group of Class } & \multicolumn{2}{|l|}{ Mean } & \multirow{2}{*}{ N-Gain } & \multirow{2}{*}{ Category } \\
\cline { 3 - 6 } & & Pre-test & Post-test & & \\
\hline 1. & Control & 45.53 & 55.53 & 0.18 & Low \\
\hline 2. & $1^{\text {st }}$ Experimental & 57.95 & 79.39 & 0.51 & Moderate \\
\hline 3. & $2^{\text {nd }}$ Experimental & 60.68 & 78.85 & 0.46 & Moderate \\
\hline
\end{tabular}

Based on Table 5, it can be seen that the student's writing skills in each class increased. Improvement of student's narrative writing skills was varying. The n-gain score of control class was 0.18 , included in the low category, while in the first experimental class, the n-gain score was 0.51 , and in the second experimental class, the n-gain score was 0.46 . The improvement of both classes included in the moderate category.

Independent and paired sample t-test are used to test the effectiveness of local wisdom-based story calendar media to improve the student's narrative writing skills. Table 6 and 7 below show the results of independent and paired sample t-test.

Table 6. Results of the independent sample t-test

\begin{tabular}{|l|l|l|l|l|}
\hline No. & Group of Class & Sig. (2-tailed) & Hypothesis & Explanation \\
\hline \multirow{2}{*}{1.} & Control & \multirow{2}{*}{0.000} & $(0.000<0.05)$ & Significant \\
\cline { 2 - 5 } & $1^{\text {st }}$ Experimental & \multirow{2}{*}{0.000} & $(0.000<0.05)$ & Significant \\
\cline { 2 - 5 } 2. & Control & $2^{\text {nd }}$ Experimental & & \\
\hline
\end{tabular}

Based on Table 6, it can be seen that the significance value in each group is smaller than 0.005 ( $\alpha$ $<0.05$ ). So, it can be concluded that there are significant differences in the average narrative essay writing skills of fourth-grade students who use and do not use the local wisdom-based story calendar media. The developed story calendar can improve students' narrative essay writing skills. The next is the results of the paired t-test. Based on theses calculation, the significance value is less than 0.05 . So, it can be 
concluded that there are differences in student's narrative writing skills before and after using the local wisdom-based story calendar media. The results of the paired t-test were presented below in Table 7.

Table 7. Results of the paired $t$-test

\begin{tabular}{|l|l|l|l|l|}
\hline No. & Group of Class & Sig. (2-tailed) & Hypothesis & Explanation \\
\hline 1. & $1^{\text {st }}$ Experimental & 0.000 & $(0.000<0.05)$ & Significant \\
\hline 2. & $2^{\text {nd }}$ Experimental & 0.000 & $(0.000<0.05)$ & Significant \\
\hline
\end{tabular}

\section{DISCUSSION AND CONCLUSIONS}

Learning can be considered successful if the learning objectives that have been submitted previously have been achieved. The achievement of learning objectives is influenced by many factors in learning activities. One of the factors that influence success in learning is the use of learning media. Learning media acts as a learning resource that makes it easy for students in the learning process (Gonçalves, Araújo, Pereira, \& Moreira, 2017).

Based on the findings, it indicates that the local wisdom-based story calendar is effective learning media to improve student's narrative writing skills. The material and media expert validations get very good categories, while teacher's and student's responses get very good categories generally. A paired and independent sample t-test has a significance score of less than 0.05 which is 0.000 . There is a significant increase in student's narrative writing skills after using the local wisdom-based story calendar as a learning media.

The use of a local wisdom-based story calendar is effective to improve student's narrative writing skills. The improvement of the student's narrative by using the local wisdom-based story calendar is caused by several reasons. The media make the learning more directed and enjoyable since it contains pictures, local wisdom-based stories, and activities that support literacy developments. Using learning media that contain pictures and stories supports children to master language skills, reading, writing, listening, and speaking (Chong, 2017; Grolig, Cohrdes, Tiffin-Richards, \& Schroeder, 2019; HertzLazarowitz, 2004; Novianti, 2016). Moreover, students also can learn and recognize their local culture, characters, and general knowledge.

In the field testing, the local wisdom-based story calendar attracts the students in the learning process. One of the reasons is because of colorful image elements in this developed media. Stewig (2013) mentioned that in the illustrations of children's books, the message of the story is strengthened by using attractive colors in the picture. This is in line with the opinion of Moore \& St. George (1991) that early childhood and elementary school children have the habit of choosing books based on their appearance and illustrations. Visual media such as pictures influence the learning process. The use of images in learning can motivate and attract students' attention so that it helps students understand the reading (Kasmaienezhadfard, Pourrajab, \& Rabbani, 2015; Shabiralyani, Hasan, Hamad, \& Iqbal, 2015). Students will be helped to understand the contents of the story in the book if it is equipped with pictures and questions (de Koning, Wassenburg, Ganushchak, Krijnen, \& van Steensel, 2020). Related to the improvement of narrative essay writing skills, pictures can also help students in the process of imagination when writing narrative essays. Asrifan (2015), Dunn \& Finley (2010), and Gutiérrez, Puello, \& Galvis (2015) argued that elements of images in a media can help students in developing a narrative essay. Students are assisted because images can be a guide for students to define elements of a story, such as themes, principles, settings, plots, and orders. Besides, visual images are also very useful to stimulate students' ideas and creativity in writing narrative essays (Listyani, 2019). The illustrations have an important role in the learning process, especially in the development of student writing skills. So, it can be concluded that the development of textbooks or media for elementary students must be adjusted to the needs of students, which includes illustrations and attractive colors to improve student's imagination and narrative writing skills.

Besides the colorful image and illustration, another element that supports the local wisdom-based story calendar is local wisdom-based stories. The element of local wisdom inherent in the story also becomes an inseparable part. Uge, Neolaka, \& Yasin (2019) mentioned that teaching materials that contain elements of local wisdom can shape students' knowledge and attitudes. Knowledge and character of students are more easily formed because students learn from their environment, so they can more easily understand the learning. Opinions about teaching materials based on local wisdom that have a positive effect on student understanding are supported by Pornpimon, Wallapha, \& Prayuth (2014) who stated that books used by teachers in teaching can be developed independently by incorporating elements of local wisdom. Thus, the development of books and learning media must be adapted to the local capacity to make it easier for students to learn. The stories based on local wisdom can improve 
students' story writing skills. This is because stories based on local wisdom are easier for students to understand. After all, they are more contextual and closer to student's learning environments (Santosa et al., 2019). The selection of local wisdom as the basis for media development is to create contextual and meaningful learning. Contextual learning is learning that the process can help students to link learning with the context of every day (Kosassy, Gistituati, Jama, \& Montessori, 2018). Learning-related to the context of the daily life of students will create meaningful learning. Ferryka (2019) and Huang et al. (2011) stated that meaningful learning is learning that is faced by students and is beneficial for daily life. Thus, in the development of this media, it chooses a base of local wisdom to facilitate students in learning comprehension.

The local wisdom-based story calendar media in addition to consisting of stories and images, also equipped with activities that can develop students' literacy skills, specifically the writing skills of narrative essays. There are six activities that are available on the Story Calendar media based on local wisdom. In the first activity, the students listen to the story read by the teacher. Listening skills relate to students' writing skills (Ciğerci \& Gultekin, 2017). Students who have good listening skills will also have a good understanding, so that it will affect their writing skills. This is in line with the opinion of Alkaaf \& AlBulushi (2017) which stated that the storytelling strategy has a positive influence on students' story writing skills. The second and third activities are creating mind maps or graphic organizers and analyzing the character's personalities in the story. Mind maps created by students are based on the results of listening to students from previous activities. If students can understand well the story read by the teacher, students will easily make mind maps. The mind map that is created is containing six question words related to the story being read. Kurnia, Arief, \& Irdamurni (2018) and Odewumi, Gambari, \& Bada (2019) stated that the graphic organizer helps elementary students in writing narrative essays. A graphic organizer helps students learn to connect the elements contained in the story (Tayib, 2015). In the fourth activity, they make an outline based on the story that was listened to previously. Pour-Mohammadi, Abidin, \& Fong (2012) and Sari (2019) stated that making an essay framework is effective in improving the narrative essay writing skills of elementary school students. The essay framework created by students helps them to arrange the order of stories so that the story has a clear plot. The fifth activity is writing stories. Writing is one of the language skills. To have good skills in writing narrative essays, students need to practice writing intensively (Langan, 2008). This is tried to be applied in this media by providing story writing activities to train students. The sixth activity is asking students to give opinions if they are one of the characters in the story. This indirectly trains students to imagine. Tok \& Kandemir (2015) explained that in creative writing learning, imagination can help students to build their skills in writing stories. Students are free to establish their imagination in the form of ideas in developing the stories they write.

The local wisdom-based story calendar developed in this research has passed the feasibility criteria to improve student's narrative writing skills based on expert validation, teacher's and student's response scale in very good criteria. The developed story calendar is effective to improve student's writing skills. Based on operational field testing, the value of significance is $<0.05$. That is 0.000 , which concludes that students who use the developed calendar media have significant differences in narrative writing skills. Through the pictures, local wisdom-based stories, and some literacy activities in the developed story calendar, elementary students can write narrative text more directed and easily.

The development of media in the local wisdom-based story calendar is only developed to improve narrative text writing skills. In further research, it can be developed for other types of texts and language skills. In addition to language skills, this media also needs to be further investigated whether it affects the cognitive and affective domains of students.

\section{ANCKNOWLEDGEMENTS}

This research was supported by the research fund provided by The Ministry of Education and Culture, the Republic of Indonesia.

\section{REFERENCES}

Alkaaf, F., \& Al-Bulushi, A. (2017). Tell and write, the effect of storytelling strategy for developing story writing skills among grade seven learners. Open Journal of Modern Linguistics, 07(02), 119-141. https://doi.org/10.4236/ojml.2017.72010

Anggraeni, K. (2017). The use of Story Calendar Media to Increase Reading Comprehension Skill in Elementary School. Advances in Social Science, Education and Humanities Research, 128, 110-114. https://doi.org/10.2991/icet-17.2017.17 
Anggraini, P., \& Kusniarti, T. (2017). Character and local wisdom-based instructional model of bahasa Indonesia in vocational high schools. Journal of Education and Practice, 8(5), 23-29.

Asrifan, A. (2015). The use of pictures story in improving students' ability to write narrative composition. International Journal of Language and Linguistics, 3(4), 244-251. https://doi.org/10.11648/j.ijll.20150304.18

Aziz, A. A., Narayanasamy, J. A. P., Mohamad, M., \& Hameed, H. A. (2019). Student-teachers' experiences in creating oral history texts. 3L: Language, Linguistics, Literature, 25(3), 79-89. https://doi.org/10.17576/3L-2019-2503-06

Birgili, B. (2015). Creative and critical thinking skills in problem-based learning environments. Journal of Gifted Education and Creativity, 2(2), 71-71. https://doi.org/10.18200/jgedc.2015214253

Chong, S. L. (2017). Many languages, whither literacy? Understanding the ontology of reading in linguistically-diverse contexts. 3L: Language, Linguistics, Literature, 23(2), 1-13. https://doi.org/10.17576/3L-2017-2302-01

Ciğerci, F. M., \& Gultekin, M. (2017). Use of digital stories to develop listening comprehension skills. Issues in Educational Research, 27(2), 252-268.

de Koning, B. B., Wassenburg, S. I., Ganushchak, L. Y., Krijnen, E., \& van Steensel, R. (2020). Inferencing questions embedded in a children's book help children make more inferences. First Language, 40(2), 172-191. https://doi.org/10.1177/0142723719894770

Detik.com. (2019). Benarkah Minat Baca Orang Indoneisa Serendah Ini? Detik.Com, p. 10. Retrieved from https://news.detik.com/berita/d-4371993/benarkah-minat-baca-orang-indonesia-serendah-ini.

Dunn, M. W., \& Finley, S. (2010). Children's struggles with the writing process exploring storytelling, visual arts, and keyboardingto promote narrative story writing. Multicultural Education, 18(1), 3342.

Egan, A., Maguire, R., Christophers, L., \& Rooney, B. (2017). Developing creativity in higher education for 21st century learners: A protocol for a scoping review. International Journal of Educational Research, 82, 21-27. https://doi.org/10.1016/j.ijer.2016.12.004

Endah, S., Effendi Thahar, H., \& Asri, Y. (2018). The contribution of reading interest on literature and reading comprehension toward students' ability in writing fantasy story. International Conferences on Education, Social Sciences and Technology, 955-960. https://doi.org/10.29210/20181137

Erdogan, V. (2019). Integrating 4c skills of 21st century into 4 language skills in EFL classes. International Journal of Education and Research, 7(11), 113-124. Retrieved from www.ijern.com

Ferryka, P. Z. (2019). Pembelajaran berbasis sosiokultural pada tema lingkungan bersih sehat dan asri di sekolah dasar. Jurnal Pena Karakter, 02(01), 35-42.

Gonçalves, A. D., Araújo, V. L. De, Pereira, S., \& Moreira, I. X. (2017). Utilizing Audiovisual Media and Learning Motivation on Student Achievement of Social Department Grade VIII Student Fatumeta, Dili. International Research-Based Education Journal, 1(1), 5-14.

Grolig, L., Cohrdes, C., Tiffin-Richards, S. P., \& Schroeder, S. (2019). Effects of preschoolers' storybook exposure and literacy environments on lower level and higher level language skills. Reading and Writing, 32(4), 1061-1084. https://doi.org/10.1007/s11145-018-9901-2

Gutiérrez, K. G. C., Puello, M. N., \& Galvis, L. A. P. (2015). Using pictures series technique to enhance narrative writing among ninth grade students at institución educativa simón araujo. English Language Teaching, 8(5), 45-71. https://doi.org/10.5539/elt.v8n5p45

Hermanto, R., \& Anisyah. (2017). Media Literasi Kalender Cerita Bermuatan Nilai. The 1st International Conference on Language, Literature and Teaching, 860-869.

Hertz-Lazarowitz, R. (2004). Storybook writing in first grade. Reading and Writing, 17(3), 267-299. https://doi.org/10.1023/B:READ.0000017689.04775.b7

Huang, Y. M., Chiu, P. S., Liu, T. C., \& Chen, T. S. (2011). The design and implementation of a meaningful learning-based evaluation method for ubiquitous learning. Computers and Education, 57(4), 22912302. https://doi.org/10.1016/j.compedu.2011.05.023

IEA. (2012). International Annual Report. Retrieved from https://www.iea.org/publications/freepublications/publication/IEA_Annual_Report_publicversion. pdf.

Iksan, Z. H., Zakaria, E., Meerah, T. S. M., Osman, K., Lian, D. K. C., Mahmud, S. N. D., \& Krish, P. (2012). Communication skills among university students. Procedia - Social and Behavioral Sciences, 59(June 2014), 71-76. https://doi.org/10.1016/j.sbspro.2012.09.247

Istiq'faroh, N., Suhardi, \& Mustadi, A. (2020). Improving elementary school students' creativity and writing skills through digital comics. Elementary Education Online, 19(2), 426-435. https://doi.org/10.17051/ilkonline.2020.689661

Kasmaienezhadfard, S., Pourrajab, M., \& Rabbani, M. (2015). Effects of pictures in textbooks on students' 
creativity. Multi Disciplinary Edu Global Quest, 2(14), 83-96.

Khan, A. R., \& Rahman, M. M. (2017). The Role of Evaluation at The Stages of Policy Formulation, Implementation, and Impact Assessment. Agathos International Journal, 8(1), 173-186.

Khoirunnisa, H., Umamah, N., \& Sumardi. (2019). Edmodo as a media for history learning in the digital era. IOP Conference Series: Earth and Environmental Science, 243(1), 1-8. https://doi.org/10.1088/1755$1315 / 243 / 1 / 012087$

Kim, Y. S. G., Petscher, Y., Wanzek, J., \& Al Otaiba, S. (2018). Relations between reading and writing: a longitudinal examination from grades 3 to 6. Reading and Writing, 31(7), 1591-1618. https://doi.org/10.1007/s11145-018-9855-4

Kosassy, S. O., Gistituati, N., Jama, J., \& Montessori, M. (2018). The implementation of contextual learning approach in e-learning based on weblog toward students learning achievements. Journal of Counseling and Educational Technology, 1(2), 59. https://doi.org/10.32698/0151

Kurnia, R., Arief, D., \& Irdamurni, I. (2018). Development of teaching material for narrative writing using graphic organizer story map in elementary school. International Journal of Research in Counseling and Education, 1(1), 22. https://doi.org/10.24036/009za0002

Lance, D. M., \& Beverly, B. (2012). School-age Language and Class- Room Success. San Diego: CA: Plural Publishing.

Langan, J. (2008). College Writing Skills with Readings (7th ed.). New York: McGraw-Hill.

Listyani. (2019). The use of a visual image to promote narrative writing ability and creativity. Eurasian Journal of Educational Research, 2019(80), 193-224. https://doi.org/10.14689/ejer.2019.80.10

Mahajan, R. (2015). The key role of communication skills in the life Of professionals. Journal of Humanities and Social Science, 20(12), 36-39. https://doi.org/10.9790/0837-201223639

Moya, M. E. G., Ortíz, L. M., \& Díaz, A. M. N. (2016). Evidence of intercultural communication competence in tenth grader's narrative texts. GiST Education and Learning Research Journal, 13(13), 111-130. https://doi.org/10.26817/16925777.315

Naz, A. A., \& Akbar, R. A. (2010). Use of media for effective instruction its importance: some consideration. Journal of Elementary Education, 18(1-2), 35-40.

Novianti, N. (2016). English literature teaching: An Indonesian context. Indonesian Journal of Applied Linguistics, 6(1), 42-49. https://doi.org/10.17509/ijal.v6i1.2660

Odewumi, M. O., Gambari, A. I., \& Bada, T. A. (2019). Efficacy of graphic organizer on junior secondary school students ' performance in cognitive writing skills. International Journal of New Trends in Arts, Sports \& Science Education, 9(2), 34-41.

OECD. (2016). Reading Performance PISA 2015. Retrieved from https://data.oecd.org/pisa/readingperformance-pisa.htm.

Pishghadam, R., \& Mehr, F. J. (2011). Learner creativity and performance in written narrative tasks. World Journal of Education, 1(2), 115-125. https://doi.org/10.5430/wje.v1n2p115

Pornpimon, C., Wallapha, A., \& Prayuth, C. (2014). Strategy challenges the local wisdom applications sustainability in schools. Procedia - Social and Behavioral Sciences, 112(1), 626-634. https://doi.org/10.1016/j.sbspro.2014.01.1210

Pour-Mohammadi, M., Abidin, M. J. Z., \& Fong, C. L. (2012). The effect of process writing practice on the writing quality of form one students: A case study. Asian Social Science, 8(3), 88-99. https://doi.org/10.5539/ass.v8n3p88

Prabavathi, R., \& Nagasubramani, P. C. (2018). Effective oral and written communication. Journal of Applied and Advanced Research, 3(S1), 29. https://doi.org/10.21839/jaar.2018.v3is1.164

Sa'idah, L., Pramuniati, I., \& Eviyanti, E. (2019). Materials development of beginning reading through big book media for students grade II SD Negeri Percobaan Medan. International Journal of Research and Review, 6(7), 545-569.

Sakat, A. A., Mohd Zin, M. Z., Muhamad, R., Ahmad, A., Ahmad, N. A., \& Kasmo, M. A. (2012). Educational technology media method in teaching and learning progress. American Journal of Applied Sciences, 9(6), 874-878. https://doi.org/10.3844/ajassp.2012.874.878

Santosa, A. B., Basuki, Y., \& Puspita, A. M. I. (2019). The effectiveness of local wisdom-based teaching materials in enhancing creative writing skills of elementary school students. Journal of English Language Teaching and Linguistics, 4(3), 349-359. https://doi.org/10.21462/jeltl.v4i3.326

Sari, D. P. (2019). Perbedaan keterampilan menulis karangan narasi dengan menggunakan teknik outline (kerangka karangan) siswa kelas v sd negeri 161 pekanbaru. Jurnal PAJAR, 3(4), 954-965.

Shabiralyani, G., Hasan, K. S., Hamad, N., \& Iqbal, N. (2015). Impact of Visual Aids in Enhancing the Learning Process Case Research: District Dera Ghazi Khan. Journal of Education and Practice, 6(19), 226-233.

Sheth, T. D. (2016). Expressive communication skills in english: A criterion for non-native L2 students. 
International Journal of Humanities, Social Sciences and Education, 3(12), 43-47. https://doi.org/10.20431/2349-0381.0312005

Stewig, J. W. (2013). Children's preference in picture book illustration. Education Leadership Journal, 31(2), 273-279. Retrieved from https://ezproxy.upsa.es/login?url=http://search.ebscohost.com/login.aspx?direct=true \&db=eric\& AN=EJ065877\&site $=$ ehost-live \&scope $=$ site

Tan, L., Lee, S., Ponnusamy, L., Koh, E., \& Tan, K. (2016). Fostering creativity in the classroom for high ability students: context does matter. Education Sciences, 6(4), 36. https://doi.org/10.3390/educsci6040036

Tayib, A.-M. (2015). The effect of using graphic organizers on writing. International Journal of English Language and Linguistics Research, 151(1), 10-17. https://doi.org/10.1145/3132847.3132886

Tok, S.., \& Kandemir, A. (2015). Effects of creative writing activities on students' achievement in writing, writing dispositions and attitude to english. Procedia - Social and Behavioral Sciences, 174, 16351642. https://doi.org/10.1016/j.sbspro.2015.01.815

Tuan, L. T. (2010). Enhancing EFL learners' writing skill via journal writing. English Language Teaching, 3(3), 81-88. https://doi.org/10.31538/alsuna.v2i2.397

Uge, S., Neolaka, A., \& Yasin, M. (2019). Development of social studies learning model based on local wisdom in improving students' knowledge and social attitude. International Journal of Instruction, 12(3), 375-388. https://doi.org/10.29333/iji.2019.12323a

Ulu, H. (2019). Investigation of fourth grade primary school students' creative writing and story elements in narrative text writing skills. International Journal of Progressive Education, 15(5), 273-287. https://doi.org/10.29329/ijpe.2019.212.18

USAID. (2014). Pembelajaran Literasi Kelas Awal di LPTK. Jakarta: USAID PRIORITAS.

Wang, Z., \& Wang, L. (2015). Cognitive development: child education. International Encyclopedia of the Social \& Behavioral Sciences: Second Edition, 4, 38-42. https://doi.org/10.1016/B978-0-08-0970868.92007-5

Zubaidah, E. (2015). Pemanfaatan media pembelajaran untuk menciptakan lingkungan kelas sd (alternatif penciptaan laboratorium sd yang efektif ). Jurnal Prima Edukasi, 3(1), 46-60. https://doi.org/10.21831/jpe.v3i1.4064 